\title{
Improvement in angina pectoris with alpha adrenoceptor blockade
}

Sir,

Collins and Sheridan (1985; 53: 488-92) reported that compared with placebo treatment the alpha blocker indoramin (given three times a day) improved exercise tolerance and increased oxygen consumption during exercise in patients with stable angina pectoris. These results are different from those reported by us. ${ }^{1}$ We studied patients with stable angina pectoris who were not taking any other antianginal drugs. In a randomised crossover study we compared the effects of single doses of 50 and 75 $\mathrm{mg}$ indoramin with those of placebo. Exercise time to the onset of angina in seconds before and after placebo and before and after 50 and $75 \mathrm{mg}$ of indoramin are shown in the table (mean (SEM)):

$\begin{array}{llll} & \text { Placebo } & \begin{array}{l}\text { Indoramin } \\ (50 \mathrm{mg})\end{array} & \begin{array}{l}\text { Indoramin } \\ (75 \mathrm{mg})\end{array} \\ \text { Control } & 279(53) & 233(43) & 267(52) \\ 1 \text { h post } & 283(49) & 313(56) & 347(55) \\ 4 \text { h post } & 347(67) & 302(47) & 341(55)\end{array}$

Thus, in contrast to the results obtained by Collins and Sheridan, we could not demonstrate any improvement in exercise performance at either of the doses of indoramin.

It is possible that the results obtained by Collins and Sheridan are different from ours because their patients were taking other antianginal agents-such as vasodilators-as well as beta blockers. Also we studied patients after single oral doses whereas Collins and Sheridan gave indoramin three times a day.

Therefore, in view of these two different reports I feel that the effect of indoramin as a single agent should be evaluated during sustained treatment in patients with exertional angina.

Udho Thadani, Cardiovascular Section, Department of Medicine,

University of Oklahoma,

Oklahoma City,

Oklahoma 73190,

USA.

\section{Reference}

1 Thadani U, Parker JO. Evaluation of alpha blockerindoramin in angina [Abstract]. Clin Pharmacol Ther 1983; 33: 211.

This letter was shown to the authors, who reply as follows:

Sir,

We have difficulty in accepting that the failure of Thadani and Parker to find an improvement in exercise performance with indoramin (based on the results presented in their comments to this journal and in the abstract cited ${ }^{1}$ ), necessarily represents the demonstration of a different response to that reported by ourselves (1985; 53: 488-92). This is because there are serious problems in the design of their study that could readily mask an improvement in response to the drug. For example there appears to have been an appreciable training effect (as indicated by the data obtained in their placebo group) and each subject received only one dose of indoramin, which, given its high first pass clearance, ${ }^{2}$ is unsuitable for this type of study. We believe that with such difficulties a study based on nine patients is almost certainly inadequate. Furthermore, the exercise durations they observed at one hour after treatment appear to have increased approximately $30 \%$ after active treatment, compared with $1 \%$ after placebo treatment, based on the means presented. For these reasons, we believe that an interpretation of their results as indicating a negative response to the drug could well be misleading.

In our paper we emphasised the importance of interpreting our results only in relation to patients already receiving beta blockade or nitrates and we agree that a careful study of a single agent with alpha adrenoceptor blockade in patients with chronic stable angina would be of interest.

Peter Collins,

Desmond Sheridan,

Department of Cardiology,

St Mary's Hospital,

Praed Street,

London W2 1NY. 


\section{References}

1 Thadani U, Parker JO. Evaluation of alpha blockerindoramin in angina [Abstract]. Clin Pharmacol Ther
1983; 33; 211.

2 Draffan GH, Lewis PJ, Firman JL, Jordan TW, Dollery CT. Pharmacokinetics of indoramin in man. $\mathrm{Br} \mathcal{F}$ Clin Pharmacol 1976; 3: 489-95.

\section{Notice}

\section{British Cardiac Society}

The Annual General Meeting for 1986 will take place in York on 2 and 3 April 1986, and the closing date for receipt of abstracts was 2 January 1986.

The Autumn Meeting will be held at the Wembley Conference Centre, London, on 25 to 27 November 1986 , and the closing date for receipt of abstracts will be 1 August 1986. 